\title{
Pendidikan Karakter Anak Usia Dini di Masa Pandemi Covid-19
}

\author{
Jauharotur Rihlah ${ }^{1)}$, Ulufiyatul Kamilah ${ }^{2)}$, Destita Shari ${ }^{3)}$ \\ ${ }^{1}$ Universitas Nahdlatul Ulama Surabaya \\ email: rihlahjauhara@unusa.ac.id \\ ${ }^{2}$ Universitas Nahdlatul Ulama Surabaya \\ email:4230016006@student.unusa.ac.id \\ ${ }^{3}$ Universitas Nahdlatul Ulama Surabaya \\ email: destita@unusa.ac.id
}

DOI: $10.31849 /$ paud-lectura.v\%vi\%i.4878

Received 7 September 2020, Accepted 22 September 2020, Published 1 Oktober 2020

\begin{abstract}
Abstrak
Penanaman nilai-nilai karakter pada anak usia dini merupakan hal paling utama dalam membentuk kepribadian anak sejak dini, hal ini berkaitan dengan pedoman pembentukan kebiasaan positif yang berperan sebagai dasar pengetahuan untuk memperoleh pendidikan selanjutnya. Penulisan penelitian ini bertujuan untuk mengetahui pendidikan karakter anak usia dini di masa pandemi covid-19. Penelitian ini merupakan penelitian deskriptif menggunakan pendekatan kuantitatif didukung dengan teknik random sampling dalam pemilihan subjek penelitian, sehingga diperoleh 30 responden anak didik di TK Dharma Wanita Kecamatan Sedati Kabupaten Sidoarjo. Teknik pengambilan data berupa kuesioner/angket yang terdiri dari 8 butir pertanyaan terkait penanaman pendidikan karakter anak usia dini yang meliputi kemandirian, percaya diri, dan tanggung jawab. Teknik analisis data yang digunakan dalam penelitian ini berupa analisis deskriptif kuantitatif berupa persentase, dari data yang didapatkan diperoleh presentase aspek penanaman pendidikan karakter berada pada kategori mulai berkembang dengan hasil $47 \%$ aspek kemandirian, $48 \%$ aspek percaya diri, dan $42 \%$ aspek tanggung jawab, sehingga perolehan hasil rata-rata penanaman pendidikan karakter selama pandemi covid-19 berada pada kategori mulai berkembang dengan nilai presentase $46 \%$.
\end{abstract}

Kata Kunci : Pendidikan Karakter; Pandemi Covid-19; Kemandirian; Tanggung Jawab; Percaya diri

\begin{abstract}
Cultivating character values in early childhood is the most important thing in shaping children's personality from an early age, this is related to the guidelines for forming positive habits that act as the basis of knowledge for further education. Writing this study aims to determine the character education of early childhood during the Covid19 pandemic. This research is a descriptive study using a quantitative approach supported by random sampling techniques in the selection of research subjects, in order to obtain 30 student respondents in TK Dharma Wanita, Sedati District, Sidoarjo Regency. The data collection technique is in the form of a questionnaire which consists of 8 questions related to the cultivation of early childhood character education which includes independence, confidence, and responsibility. The data analysis technique
\end{abstract}


used in this research is in the form of a quantitative descriptive analysis in the form of a percentage, from the data obtained, the percentage of aspects of character education cultivation is in the category of starting to develop with the results of $47 \%$ aspects of independence, $48 \%$ aspects of self-confidence, and $42 \%$ aspects of responsibility. so that the average yield of character education during the Covid-19 pandemic is in the category of starting to develop with a percentage value of $46 \%$.

Keywords: Character building; Covid-19 Pandemic; Independently; Responsible; Confidence. 


\section{PENDAHULUAN}

Anak usia dini merupakan anak yang berada pada masa golden age period, dimana terdapat perkembangan otak mencapai $80 \%$ dengan pertumbuhan 100-200 milyard sel otak, sehingga pada masa keemasan ini segudang potensi yang dimiliki anak harus dikembangkan dengan baik, hal ini merupakan waktu yang sangat tepat untuk menanamkan nilai-nilai karakter kebaikan yang bertujuan untuk membentuk kepribadian yang positif pada diri anak. Pembentukan keperibadian diperlukan untuk penanaman nilai-nilai karakter yang dapat menumbuhkan rasa percaya diri, kemandirian, dan tanggung jawab pada anak usia dini, sehingga anak dapat terhindar dari perilaku yang menyimpang di kehidupan selanjutnya. Pendidikan karakter harus dibentuk sejak anak usia dini yang bertujuan untuk memupuk nilai-nilai kebaikan pada anak yang nantinya dapat menjadi suatu kebiasaan (habit) positif yang dapat menjadi pedoman mereka ketika beranjak dewasa dan sebagai bekal pengetahuan untuk menempuh jenjang pendidikan selanjutnya (Fitriyah, 2017; Suyanto, 2012).

Penanaman nilai-nilai pendidikan karakter pada anak memerlukan peran guru dalam memberikan nilai-nilai karakter pada anak usia dini, menurut Lickona, Schaps, dan Lewis serta Azra (dalam Suyanto, 2010) pendidik diharapkan mampu memberikan pengarahan bahwa karakter anak didik muncul melalui tanggung jawab, kemandirian dan berpartisipasi dalam mengambil keputusan yang berperan pada rasa percaya diri (Purwanto dkk, 2017). Perlunya peran pendidik untuk selalu mendampingi anak usia dini dalam pembentukan pendidikan karakter agar penanaman pendidikan karakter ini berkembang secara maksimal dan sesuai tahapan perkembangan anak.

Problematika yang sedang dihadapi oleh pendidik saat ini yakni terjadi pandemi corona virus 2019 seperti yang dikemukakan Choerotunnisa (dalam Oktaria, 2020) yang mengaharuskan semua aktivitas dipusatkan di rumah mulai dari bekerja, belajar, dan sekolah melalui sistem pembelajaran daring, mengingat betapa ganas dan cepatnya penularan virus ini, maka pemerintah menginstruksikan semua elemen lembaga pendidikan untuk tetap melaksanakan proses pembelajaran melalui daring yang serba online, sehingga pendidik diharuskan mampu beradaptasi dengan sistem pendidikan yang baru dikenal dengan sebutan new normal, sehingga diperlukan kerja sama antara elemen pendidik dengan elemen keluarga agar proses pembelajaran yang dilakukan tetap berjalan dengan baik.

Tantangan baru yang dihadapi pendidik dan orang tua dapat mendampingi anak belajar dari rumah membuat orang tua merasa kesulitan dan keberatan akan tugas yang diberikan kepada anak didik, karena orang tua tidak mampu mendampingi anaknya dalam belajar dan ketidak tegasan orang tua untuk tidak menuruti keinginan anak, sehingga menghambat pemberian stimulusi perkembangan pada anak dikarenakan proses 
penanaman pendidikan karakter pada anak usia dini tidak berjalan maksimal.

Penelitian ini sangat penting karena berkaitan dengan penanaman pendidikan karakter yang harus diberikan sejak usia dini, banyaknya hambatan yang dialami pendidik dalam memberikan stimulasi penanaman pendidikan karakter yang tidak seperti biasa, karena tidak bertatap muka langsung dengan anak didik melainkan melalui sistem daring, mengingat saat ini pandemi covid-19 di Indonesia masih terus bertambah jumlah penderitanya, sehingga pembiasaan new normal harus terlaksana dengan maksimal antara pendidik dan orang tua anak didik.

Berdasarkan hasil pengamatan yang dilakukan peneliti di Kecamatan Sedati Kabupaten Sidoarjo, peneliti mendapati banyak orang tua yang kurang peduli terkait pembelajaran daring yang saat ini diterapkan pada anak, sehingga pendidik merasa kesulitan dalam menanamkan pendidikan terutama pendidikan karakter kepada anak usia dini, terutama pada penanaman pendidikan karakter pada pemberian tanggung jawab pada anak, hasilnya anak tidak mau mengerjakan tugas yang diberikan pendidik, akibatnya anak bermanja kepada orang tua dan orang tua yang akhirnya menyelesaikan tugas yang diberikan pendidik dari anak didik. Mengingat anak usia dini merupakan anak yang berada pada puncak perkembangannya, sehingga perlu bantuan dan bimbingan pendidik dan perlu adanya kerjasama antara orang tua dan pendidik untuk kesuksesan pemberian stimulasi perkembangan pada anak usia dini yang sesuai tahapan perkembangan anak.

Menurut Yamin dan Sanan (dalam Riyadi, 2016), kemandirian merupakan keahlian pertama dalam hidup yang merupakan suatu kebutuhan yang harus diterapkan sejak usia dini. Pembentukan kepribadian yang mandiri pada anak memerlukan proses secara bertahap, diperlukan strategi untuk menstimulasi kemandiraian pada anak sesuai tahapan perkembangan anak. Kemandirian merupakan salah satu aspek terpenting dalam perkembangan anak, sehingga setiap individu harus memiliki karakter kemandirian, yang bertujuan untuk mewujudkan tujuan hidup, memperoleh penghargaan serta dapat berada pada puncak kesuksesan, ketika anak tidak dapat mandiri maka akan sulit anak melewati fase-fase perkembangan selanjutnya dan tidak akan maksimal, dapat dikatakan mandiri ketika mereka telah menyelesaikan tugas-tugas perkembangannya, tanpa memerlukan bantuan dari orang tua maupun pendidik. (Bibigul, Orynkul, Lyudmila, \& Aelita, 2015; Novena \& Kriswandani, 2018; Scherer \& Siddiq, 2019; Widianawati, 2011).

Rumusan masalah pada penelitian ini adalah bagaimana pendidikan karakter anak usia dini di masa pandemi covid-19. Penelitian ini bertujuan untuk mengetahui pendidikan karakter anak usia dini di masa pandemi covid-19. Manfaat penelitian ini, yakni a) Bagi peneliti, hasil penelitian digunakan sebagai referensi penelitian selanjutnya, b) Bagi pendidik, dapat menjadi pengetahuan baru terkait gambaran 
pendidikana karakter di masa pandemi, c) Bagi sekolah, sebagai bahan referensi untuk meningkatkan pembelajaran yang lebih inovatif agar penanaman pendidikan karakter anak usia dini berjalan maksimal sesuai tahapan perkembangan anak.

Menurut Fadilah dan Lilif (dalam Rohyati, 2015) tanggung jawab merupakan suatu sikap dan perilaku anak usia dini yang mampu melaksanakan tugas dan kewajiban yang diberikan bahwa anak mampu melaksanakannya, tanggung jawab yang diajarkan berasal dari tanggung jawab sederhana seperti membiasakan anak untuk menghargai waktu, menjaga barang miliknya, dan mengembalikan benda ditempatnya, semua itu perlu adanya bimbingan secara bertahap agar anak mampu melewati fase perkembangannya secara maksimal.

$$
\text { Dariyo (dalam Latifah) }
$$

berpendapat bahwa percaya diri (selfconfident) merupakan keahlian anak dalam memahami dan mempercayai bahwa seluruh potensi yang dimilikinya dapat digunakan sebaik mungkin untuk beradapatasi dengan lingkungannya, jika konsep pendidikan karakter percaya diri ini ditumbuhkan sejak dini maka akan terbentuk inisiatif, kreatif, dan optimis anak terkait masa depannya, kelebihan dan kekurangan yang dimilikinya, selalu berpikir positif dalam setiap permasalahan yang muncul dengan berasumsi bahwa pasti ada jalan keluarnya. Anak yang tidak dibangun rasa percaya dirinya maka akan muncul tanda-tanda pesimis dan selalu melemahkan semangat hidupnya.
Penelitian yang dilakukan oleh Cipta Pramana (2020) yang berjudul "Pembelajaran Pendidikan Anak Usia Dini (PAUD) di Masa Pandemi Covid19" menyatakan bahwa banyak tantangan dan hambatan dalam pelaksanaan pembelajaran secara daring, baik oleh institusi pendidikan, guru, siswa dan orang tua. Dengan belajar jarak jauh tentu dirasakan sangat berbeda bila dibandingkan dengan belajar di sekolah, baik dari segi proses pembelajaran, metode belajar, respon siswa terhadap materi pelajaran, dan kesehatan mental-sosial.

\section{METODE}

Penelitian ini menggunakan penelitian deskriptif dengan pendekatan kuantitatif, seperti yang dikemukakan Arikunto (dalam Raihan 2015) bahwa tujuan penelitian deskriptif bukan menjadi tolak ukur suatu hipotesis tertentu, melainkan hanya berupa gambaran suatu variabel yang digunakan, variabel yang mendasari penelitian ini yakni pendidikan karakter pada anak usia dini. Subjek pada penelitian ini adalah anak usia 5-6 tahun di TK Dharma Wanita Kecamatan Sedati Kabupaten Sidoarjo, sebanyak 30 responden anak didik, jumlah jenis kelamin perempuan dan laki-laki masing-masing 12 dan 18 anak didik. Teknik pengumpulan data pada penelitian ini berupa angket/kuesioner berjumlah 8 butir pertanyaan yang diisi oleh orang tua anak usia dini melalui google form mengingat saat ini masih pandemi covid-19. Instrumen penelitian yang digunakan berupa lembar kuesioner yang diisi oleh orang tua anak didik sebagai pengamat ketika proses pembelajaran daring yang telah dilakukan di rumah. Berikut ini penjabaran instrumen penelitian dan 
rubrik penilaian yang menjadi tolak ukur perolehan data sesuai tabel 1 dan tabel 2

Tabel 1 Instrumen Penelitian

\begin{tabular}{|c|c|c|}
\hline Variabel & Aspek & Indikator \\
\hline \multirow[t]{3}{*}{ Kemandirian } & \multirow{2}{*}{$\begin{array}{l}\text { Kemandirian } \\
\text { sosial dan } \\
\text { emosi }\end{array}$} & $\begin{array}{l}\text { Mengendalikan } \\
\text { emosi }\end{array}$ \\
\hline & & Mau berbagi \\
\hline & $\begin{array}{l}\text { Kemandirian } \\
\text { fisik dan } \\
\text { fungsi tubuh }\end{array}$ & $\begin{array}{l}\text { Kemampuan } \\
\text { motorik }\end{array}$ \\
\hline Percaya Diri & $\begin{array}{l}\text { Rasa percaya } \\
\text { diri }\end{array}$ & $\begin{array}{l}\text { Mampu } \\
\text { menyampaikan } \\
\text { keinginan atau } \\
\text { pendapat }\end{array}$ \\
\hline \multirow[t]{5}{*}{$\begin{array}{l}\text { Tanggung } \\
\text { Jawab }\end{array}$} & $\begin{array}{l}\text { Menjaga } \\
\text { barang } \\
\text { miliknya }\end{array}$ & $\begin{array}{l}\text { Anak didik } \\
\text { merawat barang } \\
\text { yang dimilkinya }\end{array}$ \\
\hline & $\begin{array}{l}\text { Mengerjakan } \\
\text { tugas yang } \\
\text { diberikan }\end{array}$ & $\begin{array}{l}\text { Anak } \\
\text { mengerjakan } \\
\text { tugas sesuai apa } \\
\text { yang diberikan }\end{array}$ \\
\hline & $\begin{array}{l}\text { Meletakkan } \\
\text { barang sesuai }\end{array}$ & $\begin{array}{l}\text { Anak } \\
\text { mengembalikan }\end{array}$ \\
\hline & tempatnya & $\begin{array}{l}\text { barang yang } \\
\text { telah digunakan } \\
\text { ke tempatnya }\end{array}$ \\
\hline & $\begin{array}{l}\text { Anak dapat } \\
\text { menghargai } \\
\text { waktu }\end{array}$ & $\begin{array}{l}\text { Anak } \\
\text { mengerjakan } \\
\text { tugas dengan } \\
\text { tepat waktu }\end{array}$ \\
\hline
\end{tabular}

Tabel 2 Rubrik Penilaian

\begin{tabular}{|c|c|c|c|c|}
\hline No. & Aspek & Indikator & Deskripsi & Skor \\
\hline \multirow{6}{*}{1.} & \multirow{6}{*}{$\begin{array}{c}\text { Kemandirian } \\
\text { sosial dan } \\
\text { emosi }\end{array}$} & \multirow{4}{*}{$\begin{array}{c}\text { Mengendalikan } \\
\text { emosi }\end{array}$} & $\begin{array}{l}\text { Anak mampu } \\
\text { mengendalikan } \\
\text { emosi }\end{array}$ & 4 \\
\hline & & & $\begin{array}{l}\text { Anak mampu } \\
\text { mengendalikan } \\
\text { emosi dengan } \\
\text { motivasi }\end{array}$ & 3 \\
\hline & & & $\begin{array}{l}\text { Anak mampu } \\
\text { mnegendalikan } \\
\text { emosi dengan } \\
\text { bantuan orang } \\
\text { disekitamya }\end{array}$ & 2 \\
\hline & & & $\begin{array}{l}\text { Anak tidak mampu } \\
\text { mengendalikan } \\
\text { emosi }\end{array}$ & 1 \\
\hline & & & $\begin{array}{l}\text { Anak mampu } \\
\text { berbagi kepada siapa } \\
\text { saja }\end{array}$ & 4 \\
\hline & & & $\begin{array}{l}\text { Anak mampu } \\
\text { berbagi kepada siapa } \\
\text { saja dengan motivasi }\end{array}$ & 3 \\
\hline
\end{tabular}

\begin{tabular}{|c|c|c|c|c|}
\hline & & Mau berbagi & \begin{tabular}{|l|} 
Anak mampu \\
berbagi kepada siapa \\
saja dengan bantuan \\
orang disekitamya
\end{tabular} & 2 \\
\hline & & & \begin{tabular}{|l|} 
Anak tidak mampu \\
berbagi kepada siapa \\
saja \\
\end{tabular} & 1 \\
\hline 2. & $\begin{array}{l}\text { Kemandirian } \\
\text { fisik dan } \\
\text { fungsi tubuh }\end{array}$ & $\begin{array}{c}\text { Kemampuan } \\
\text { motorik }\end{array}$ & $\begin{array}{l}\text { Anakmampu } \\
\text { memakai baju } \\
\text { sendiri }\end{array}$ & 4 \\
\hline & & & $\begin{array}{l}\text { Anakmampu } \\
\text { memakai baju }\end{array}$ & 3 \\
\hline & & & dengan motivasi & \\
\hline & & & \begin{tabular}{|l|} 
Anakmampu \\
memakai baju \\
dengan bantuan \\
orang disekitamya
\end{tabular} & 2 \\
\hline & & & $\begin{array}{l}\text { Anak tidakmampu } \\
\text { memakai baju } \\
\text { sendiri } \\
\end{array}$ & 1 \\
\hline & & Mampu & $\begin{array}{l}\text { Anakmampu } \\
\text { menvampaikan } \\
\text { keinginannya }\end{array}$ & 4 \\
\hline & & $\begin{array}{c}\text { keinginan atau } \\
\text { pendapat }\end{array}$ & $\begin{array}{l}\text { Anak mampu } \\
\text { menvampaikan } \\
\text { keinginannya } \\
\text { dengan motivasi } \\
\end{array}$ & 3 \\
\hline 3. & diri & & $\begin{array}{l}\text { Anakmampu } \\
\text { menyampaikan } \\
\text { keinginannya } \\
\text { dengan bantuan } \\
\text { orang disekitamya } \\
\end{array}$ & 2 \\
\hline & & & \begin{tabular}{|l} 
Anakt tidakmampu \\
menyampaikan \\
keinginannya \\
\end{tabular} & 1 \\
\hline & & & $\begin{array}{l}\text { Anak mampu } \\
\text { merawat barang } \\
\text { miliknya }\end{array}$ & 4 \\
\hline & Menjaga & Anak didik & $\begin{array}{l}\text { Anak mampu } \\
\text { merawat barang } \\
\text { miliknva dengan } \\
\text { motivasi }\end{array}$ & 3 \\
\hline 4. & $\begin{array}{l}\text { barang } \\
\text { miliknya }\end{array}$ & $\begin{array}{l}\text { merawat } \\
\text { barang yang } \\
\text { dimilkinya }\end{array}$ & \begin{tabular}{|l|} 
Anak mampu \\
merawat barang \\
miliknya dengan \\
bantuan orang \\
disekitamya \\
\end{tabular} & 2 \\
\hline & & & $\begin{array}{l}\text { Anak tidak mampu } \\
\text { merawat barang } \\
\text { miliknya }\end{array}$ & 1 \\
\hline
\end{tabular}




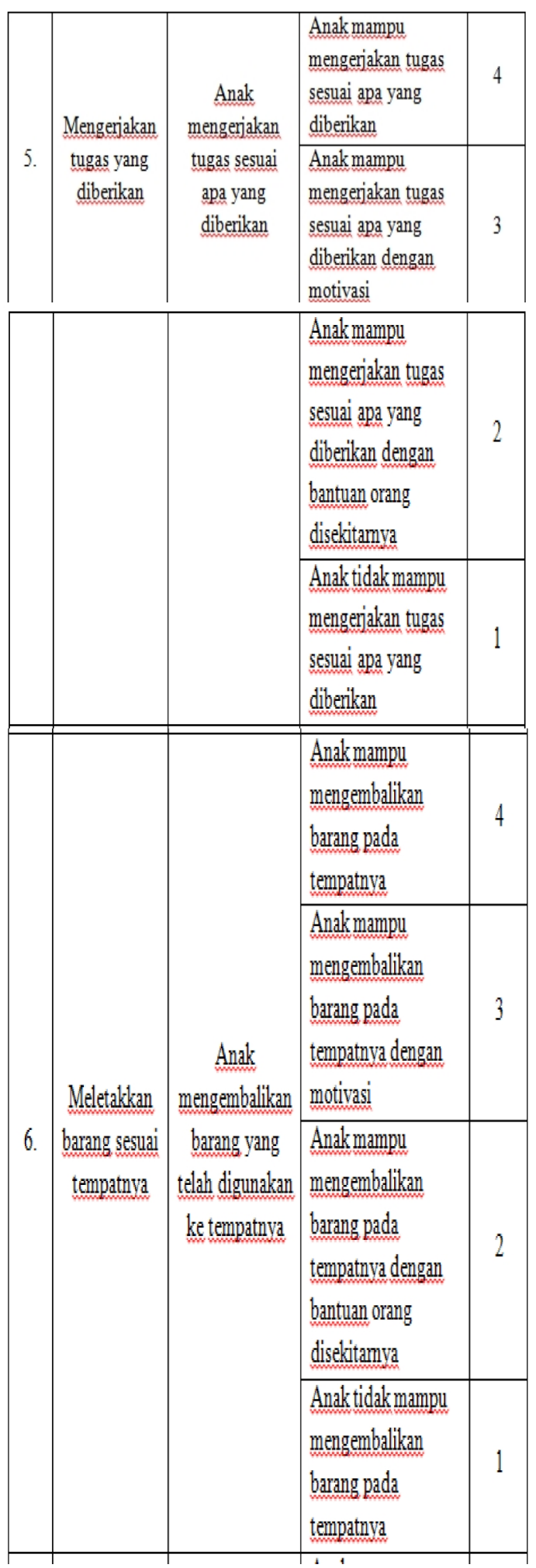

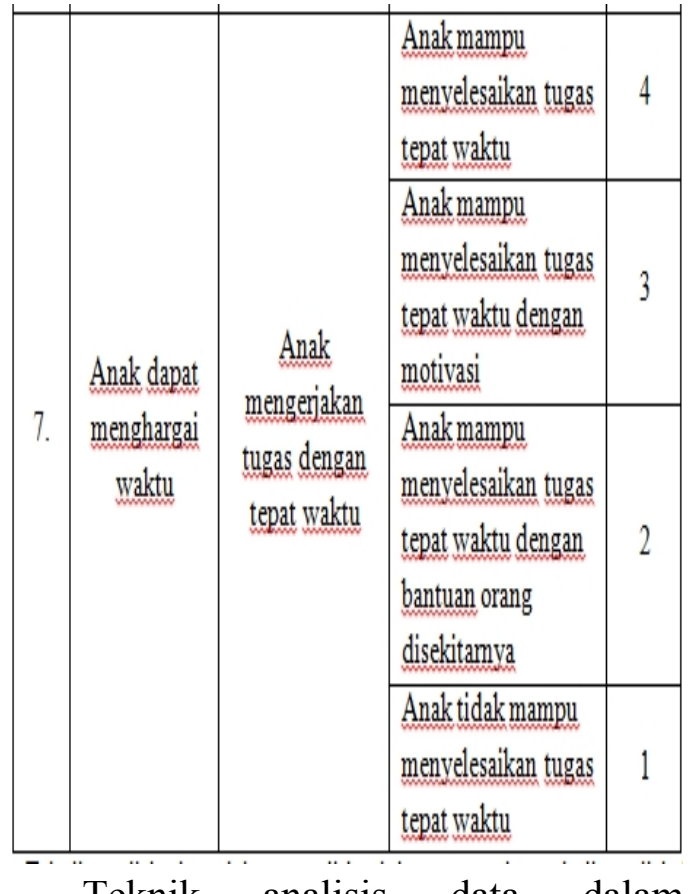

Teknik analisis data dalam penelitian ini menggunakan teknik analisis deskriptif kuantitatif, data yang diperoleh berupa angka yang kemudian diolah dengan tujuan untuk mengetahui presentase pendidikan karakter anak usia dini, selanjutnya data yang diperoleh dari lembar angket/kuesioner melalui google form dianalisis dalam bentuk presentase dengan menggunakan rumus analisis deskriptif persentase seperti pendapat Ali (dalam Sari 2016). Berikut ini rumus analisis deskriptif:

$$
\%=\frac{n}{N} \times 100
$$

Keterangan:

$\%=$ Persentase aspek pendidikan karakter anak

$\mathrm{n}=$ jumlah skor perolehan anak

$\mathrm{N}=$ skor yang seharusnya diperoleh anak

\section{HASIL DAN PEMBAHASAN}

Penelitian ini berlangsung saat pandemi covid-19 sehingga proses pembelajaran tidak berlangsung secara 
tatap muka melainkan melalui daring, sehingga proses penanaman karakter pada anak mengalami hambatan, karena tidak adanya interaksi antara pendidik dan anak didik secara langsung. Berikut hasil observasi pendidikan karakter anak usia 5-6 tahun di masa pandemi covid-19 TK Dharma Wanita Kecamatan Sedati Kabupaten Sidoarjo yang tercantum pada tabel 3

Tabel 3 Hasil Observasi

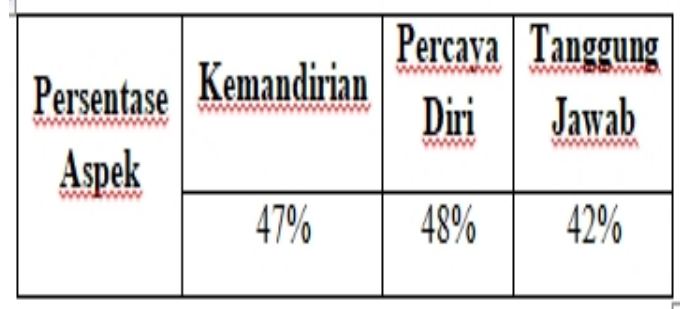

Tabel 4 Grafik Aspek Pendidikan Karakter

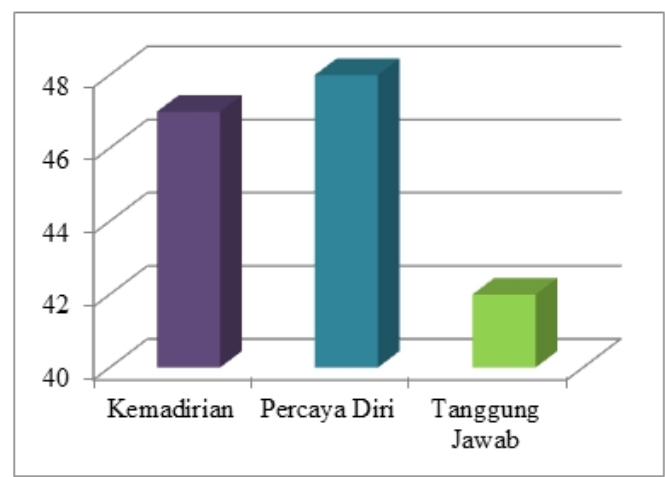

Dari data hasil observasi penanaman karakter pada anak usia dini di masa pandemi covid-19 yang terdiri dari tiga aspek penanaman karakter yang berupa aspek kemandirian, percaya diri, dan tanggung jawab di TK Dharma Wanita Kecamatan Sedati Kabupaten Sidoarjo menunjukkan bahwa pendidikan karakter anak usia dini berada pada tingkat mulai berkembang, seharusnya untuk penanaman pendidikan karakter anak usia dini usia 5-6 tahun berada pada tahap berkembang sesuai harapan, karena tahapan perkembangan yang dilalui anak harus tuntas ketika anak memasuki pendidikan selanjutnya. Pada grafik diatas diperoleh nilai presentase kemandirian anak berada pada angka $47 \%$ berada pada kategori sedang, selanjutnya untuk aspek percaya diri anak berada pada angka $48 \%$ berada pada kateogi tinggi, dan kategori rendah menempati aspek tanggung jawab yakni pada angka $42 \%$.

Hasil penelitian ini sejalan dengan penelitian yang dilakukan oleh Reswita (2017) yang menyatakan bahwa ada pengaruh positif dan signifikan antara pola asuh orangtua dengan hasil belajar anak dengan kategori sangat kuat, sehingga orang tua mempunyai peran penting dalam proses pembelajaran anak dan sangat membantu pendidik dalam memberikan stimulasi yang tepat seperti saat ini pembelajaran melalui daring.

Dari data yang diperoleh penanaman pendidikan karakter pada anak usia dini di masa pandemi covid19 tidak maksimal, karena dapat dilihat dari perolehan data yang berada pada tingkat mulai berkembang, sehingga diperlukan kerja sama antara pendidik dan orang tua agar upaya pemberian stimulasi yang diberikan pendidik melalui pembelajaran daring dapat optimal, maka orang tua diharapkan mampu memberikan bantuan atau bimbingan secara optimal dengan tidak memanjakan anak, mengingat pendidikan karakter merupakan hal utama yang harus ditanamkan sejak usia dini. Sejalan dengan penelitian yang dilakukan oleh Fitri (2020) menyatakan bahwa pembelajaran melalui daring dapat meningkatkan motivasi belajar anak dengan ketentuan adanya dukungan antara orang tua dan pendidik, diperlukan adapatasi antara orang tua dan pendidik dalam memanfaatkan teknologi pembelajaran 
daring, sehingga tercipta pembelajaran yang menyenangkan dan menyampaian materi yang diberikan pendidik dapat terlaksana sesuai harapan. Penelitian ini sinkron dengan penelitian yang dilakukan oleh Oktaria (2020) menyebutkan bahwa seluruh orang tua anak didik yakni berjumlah sepuluh orang mengatakan prihatin dengan keadaan saat ini, karena peran pendidik tidak mudah untuk dijalani, sehingga orang tua berupaya melakukan kerja sama antara pendidik agar anak mereka mampu melewati tahapan perkembangannya dengan maksimal.

Peran utama pendidik dalam pemberian stimulasi pada anak di saat pandemi covid-19 diharapkan mampu menciptakan suasana belajar yang menyenangkan sesuai prinsip pendidikan anak usia dini yakni bermain sambil belajar dan belajar seraya bermain. Hal ini sepakat dengan penelitian yang dilakukan Amalina (2020) menyatakan bahwa pembelajaran pada anak usia dini di masa pandemi covid-19 diharapkan mampu menciptakan pembelajaran yang menyenangkan dan objek pembelajaran yan sesuai, sedangkan menurut Fadlillah (2020) dan Hidayah (2019) mengatakan bahwa upaya pemilihan strategi pendidik yang tepat dengan memperhatikan karakteristik, sifat, dan hakikat anak bertujuan meningkatkan motivasi belajar anak didik dalam kebijakan pembelajaran di masa pandemi covid-19 dengan mempublikasikan hasil karya anak didik, dengan ini dapat meningkatkan motivasi belajar anak didik, meskipun masih ada rintangan yang dihadapi pendidik berkaitan dengan aspek orang tua, instrumen pembelajaran dan inovasi pendidik.

\section{KESIMPULAN}

Berdasarkan hasil observasi yang dilakukan peneliti terkait pendidikan karakter anak usia dini di masa pandemi covid-19 diperoleh kesimpulan sebagai berikut :

a. Perolehan rata-rata pendidikan karakter sebesar $46 \%$ dengan kategori mulai berkembang (MB), sehingga diperlukan stimulasi yang tepat melalui pembelajaran yang inovatif untuk meningkatkan kemampuan anak didik menjadi berkembang sesuai harapan (BSH).

b. Pendidik tidak dapat berkerja sendiri tanpa bantuan dan bimbingan orang tua yang senantiasa menemani anak dalam proses pembelajaran daring mengingat masih berlangsungnya pandemi covid-19.

Berdasarkan kesimpulan penelitian di atas dengan judul gambaran pendidikan karakter anak usia dini di masa pandemi covid-19 memperoleh saran yakni :

a. Bagi sekolah, diharapkan mampu memberikan pengarahan kepada pendidik untuk senantiasa memberikan pembelajaran yang inovatif, terutama untuk meningkatkan penanaman pendidikan karakter anak usia dini selama masa pandemi covid-19.

b. Bagi pendidik, diharapkan mampu memberikan pelayanan yang terbaik untuk anak usia dini terkait penanaman pendidikan karakter dengan cara bekerja sama dengan orang tua anak usia dini untuk bersikap tegas dan tidak memanjakan anak, pendidik juga diharapkan mampu memberikan pengetahuan 
terkait dampak penanaman karakter pada anak usia dini.

c. Bagi peneliti selanjutnya, dapat memodifikasi penelitian lebih lanjut dengan mempertimbangkan faktor lain yang dapat memperluas pengetahuan praktisi pendidikan.

\section{DAFTAR PUSTAKA}

[1]. Amalina. 2020. Pembelajaran Matematika Anak Usia Dini di Masa Pandemi Covid-19 Tahun 2020. Jurnal Obsesi : Jurnal Pendidikan Anak Usia Dini. Volume 5 Issue 1 (2021) Pages 538-548.

\section{https://doi.org/10.31004/obsesi.v5i} 1.592

[2]. Bibigul, A., Orynkul, S., Lyudmila, K., \& Aelita, S. 2015. The Rating System of the Rural School Pupils' Assessment of the Republic of Kazakhstan. Procedia - Social and Behavioral Sciences, 186, 11521158 .

https://doi.org/10.1016/j.sbspro.201 5.0\%204.127

[3]. Fadlillah, Azizah Nurul. 2020. Strategi Menghidupkan Motivasi Belajar Anak Usia Dini Selama Pandemi COVID-19 melalui Publikasi. Jurnal Obsesi : Jurnal Pendidikan Anak Usia Dini. Volume 5 Issue 1 (2021) Pages 373-384.

https://doi.org/10.31004/obsesi.v5i 1.548

[4]. Fitri, Mardi. 2020. Pengaruh Emergency Remote Learning Untuk Melihat Motivasi Belajar Anak Usia Dini. Child Education Journal. Volume 2, No. 2, 68-82 https://doi.org/10.33086/cej.v2i2.15 91

[5]. Fitriyah, Fifi Khoirul., \& Budi Purwoko. 2017. Youth Narcissistic And Aggression: A Challenge For
Guidance And Counseling Service In University. ICEI Volume 173 nc/4.0/.

http://creativecommons.org/license s/by

[6]. Hidayah, Devi S. N \& Kuswanto, Cahniyo W. 2019. Implementasi Pendidikan Karakter Anak Usia Dini melalui Metode Bermain Peran Usia 5-6 Tahun di Taman Kanak-Kanak An-Nahl Bandar Lampung. PAUD Lectura: Jurnal Pendidikan Anak Usia Dini, Vol 3, No https://doi.org/10.31849/paudlectura.v3i01.3080

[7]. Latifah, dkk. Tanpa Tahun. Gambaran Penanaman Rasa Percaya Diri Anak Usia Dini Oleh Guru Di Lembaga PAUD Adzkia Iii Kelurahan Korong Gadang, Kecamatan Kuranji, Kota Padang. Jurnal Pendidikan Luar Sekolah. http://ejournal.unp.ac.id/index.php/ pnfi/

[8]. Macmud, M. (2016). Tuntunan Penulisan Tugas Akhir Berdasarkan Prinsip Dasar Penelitian Ilmiah. Retrieved from http://researchreport.umm.ac.id/index.php/researc h-report/article/view/872

[9]. Moleong, L. J. (2006). Metodologi Penelitian Kualitatif. Bandung: Rosda Karya.

[10]. Novena, V. V., \& Kriswandani, K. 2018. Pengaruh Model Pembelajaran Probing Prompting Terhadap Hasil Belajar Ditinjau Dari Self-Efficacy. Scholaria: Jurnal Pendidikan Dan Kebudayaan, 8(2), 189-196. https://doi.org/10.24246/j.js.2018.v 8.i2.\%20p189-196

[11]. Oktaria, Renti \& Putra, Purwanto. 2020. Pendidikan Anak Dalam Keluarga Sebagai Strategi Pendidikan Anak Usia Dini Saat 
Pandemi Covid-19. Jurnal Ilmiah PESONA PAUD Vol 7, No. 1 (2020) p-ISSN 2337-8301; e- ISSN 2656-1271

http://ejournal.unp.ac.id/index.php/ paud/index

[12]. Pramana, Cipta. 2020. Pembelajaran Pendidikan Anak Usia Dini (PAUD) Dimasa Pandemi Covid-19. Indonesian Journal of Early Childhood: Jurnal Dunia Anak Usia Dini Volume 2 Nomor 2 Juli 2020 e-ISSN: 26556561

http://jurnal.unw.ac.id:1254/index.p hp/IJEC

[13]. Purwanto, dkk. 2012. Pengembangan Nilai-Nilai Karakter Anak Usia Dini Melalui Pembiasaan dan Keteladanan. Jurnal Ilmu Pendidikan, Volume 6, Edisi 2.

[14]. Reswita. 2017. Hubungan Pola Asuh Orangtua Dengan Capaian Perkembangan Anak. PAUD. Lectura: Jurnal Pendidikan Anak Usia Dini, Vol 1, No 1, Oktober 2017.

https://doi.org/10.31849/paudlectur a.v1i1.506

[15]. Riyadi, Eko Nur. 2016. Tingkat Kemandirian Anak Taman KanakKanak Islam Terpadu Mutiara Insani Brosot Galur Kulon Progo. Fakultas Ilmu Pendidikan. Universitas Negeri Yogyakarta. Skripsi Tidak Diterbitkan.

[16]. Rohyati.2015. Peningkatan Sikap Tanggung Jawab Anak Usia 5-6 Tahun Melalui Metode Proyek di TK Tunas Ibu Kalasan. Fakultas Ilmu Pendidikan. Universitas Negeri Yogyakarta. Skripsi Tidak Diterbitkan.

[17]. Sari, Evi Yunita., dkk. 2016. Profil Kemampuan Kerjasama Siswa Dalam Pembelajaran Ipa (Studi Deskriptif pada Siswa Kelas
IV dan $V$ Semester Genap SD Negeri 1 Rajabasa Jaya Bandar Lampung Tahun Ajaran 2015/2016)

[18]. Scherer, R., \& Siddiq, F. 2019. The relation between students' socioeconomic status and ICT literacy: Findings from a metaanalysis. Computers \& Education, 138 , 13-32. https://doi.org/10.1016/J.COMPED U.2 019.04.011

[19]. Suyanto, Slamet. 2012. Pendidikan Karakter untuk Anak Usia Dini. Jurnal Pendidikan Anak. Volume 1, Edisi

[20]. Widianawati, N. (2011). Pengaruh Pembelajaran Gerak dan Lagu dalam Meningkatkan Kecerdasan Musikal dan Kecerdasan Kinestetika Anak Usia Dini. Jurnal Penelitian Pendidikan, 2(Edisi Khusus), 220-228. Retrieved from http://www.academia.edu/downloa

d/34 063262/22-

NANA_WIDHIANAWATI-bl.pdf 